\title{
COMMENT
}

\section{Human Embryos, Patents, and the Thirteenth Amendment}

\section{INTRODUCTION}

The idea of patenting human life is relatively new and there is no general agreement on whether laws prevent the patenting of humanembryo inventions. The United States Constitution grants Congress the power "To Promote the Progress of Science and useful Arts, by securing for limited Times to Authors and Inventors the exclusive Right to their respective Writings and Discoveries." " From this constitutional grant of authority, Congress established the Patent Act of $1790,{ }^{2}$ creating a patent system for the purpose of promoting the innovation and commercialization of new technologies. ${ }^{3}$ Even more recently, Congress passed the 1952 Patent $\mathrm{Act}^{4}$ in an effort to strengthen the patent system. ${ }^{5}$ Essentially, a patent gives its holder the right to exclude others from making, using, or selling the patented invention. ${ }^{6}$ The right to exclude, however, should not be confused with the right to practice the invention. ${ }^{7}$ In fact, a patent holder can only practice, i.e., make, use, or sell, the patented invention, if other patents do not exist regarding the same subject matter and if there is no federal or state regulation preventing the

* Jonathan Grossman. J.D. candidate 2008, University of Kansas School of Law; B.S. 2005, Northwestern University. I would like to thank Dr. Andrew Torrance for his wonderful guidance in undertaking this topic for discussion. I'd also like to thank Crissa Seymour Cook and the rest of the Review for their tireless editorial work in shaping this Comment.

1. U.S. CONST. art. I, $\S 8$, cl. 8 .

2. Patent Act of 1790, 1 Stat. 109 (1790), repealed by Patent Act of 1793, ch. 11, 2 Stat. 318 (1793).

3. See Robert P. Merges et al., Intellectual Property in the New Technological AGE 121 (4th ed. 2006) (discussing the history of the United States patent system).

4. 1952 Patent Act, 35 U.S.C. $\S 1$ et seq. (2000).

5. See Merges et AL., supra note 3, at 122.

6. See 35 U.S.C. $§ 154(\mathrm{~d})(1)(A)$ (allowing patent holders to recover reasonable royalties when others make, use, offer to sell, or sell the patented invention); see also MERGES ET AL., supra note 3, at 126 (noting that a "patent confers the right to exclude others").

7. Merges ET AL., supra note 3, at 126-27 (giving two reasons why a patent is not an affirmative right —one, the government may prohibit practicing the invention; two, there may be existing patents excluding the patent holder from practicing the invention). 
practice of the patented activity. ${ }^{8}$ Currently, the range of patentable subject matter is very broad, but the idea of patenting living organisms is relatively new. ${ }^{9}$

Nearly 140 years after the establishment of the patent system, Congress took its first affirmative step toward allowing patents for living organisms when it passed the 1930 Plant Patent Act. ${ }^{10}$ However, the Plant Patent Act was just the beginning for patents involving life as Congress further expanded the scope of patentable subject matter with the Plant Variety Protection Act in $1970 .{ }^{11}$ In addition to congressional acceptance of patents involving life, the Supreme Court of the United States embraced the patentability of living organisms by upholding a patent for genetically engineered, oil-eating bacteria, stating that patentable subject matter includes " "anything under the sun that is made by man." "12 The Court's holding, however, is qualified by a prior holding, which distinguished between discoveries and inventions. In 1948 , the Court held unpatentable an unnatural combination of naturally occurring bacteria, finding the combination was a discovery and not an invention. ${ }^{13}$ Despite the distinction between discoveries and inventions, the first patent covering a mammal was issued in $1988,{ }^{14}$ and today "patentable biotechnology includes genetically manipulated animals such as rats, pigs, sheep, and even genetically manipulated foods such as tomatoes, rice, and corn." 15

Patents involving human life have created recent controversy, and the United States Patent and Trademark Office's (USPTO) stance on the matter is not abundantly clear. Although the USPTO has made

8. Id.

9. Diamond v. Chakrabarty, 447 U.S. 303, 308-09 (1980) (defining the modern legal standard for patentable subject matter).

10. 35 U.S.C. $\S \S 161-164$ (2000). This Act states that anyone who "invents or discovers and asexually reproduces any distinct and new variety of plant, including cultivated sports, mutants, hybrids, and newly found seedlings, other than a tuber propagated plant or a plant found in an uncultivated state, may obtain a patent." Id. $\S 161$.

11. See 7 U.S.C. $\S \S 2321$ et seq. (2000) (providing patent-like protection similar to the protection provided by the Plant Patent Act, but for sexually reproducing plant species).

12. See Diamond, 447 U.S. at 303, 309 (quoting congressional intent for patentable subject matter).

13. See Funk Bros. Seed Co. v. Kalo Inoculant Co., 333 U.S. 127, 130 (1948) ("He who discovers a hitherto unknown phenomenon of nature has no claim to a monopoly of it which the law recognizes.").

14. See U.S. Patent No. 4,736,866 (filed June 22, 1984) (patenting a mouse genetically engineered to be particularly susceptible to cancer).

15. See Robert Greene Sterne \& Lawrence B. Bugaisky, The Expansion of Statutory Subject Matter Under the 1952 Patent Act, 37 AKRON L. REV. 217, 224 (2004) (discussing the breadth of statutory subject matter for patents). 
statements denying the patentability of human life, patents involving human embryos already exist. ${ }^{16}$ For example, in 2001 the USPTO issued a patent with claims covering a process of cloning mammals and the products produced by the process, i.e., the cloned mammals themselves, which implicates the human embryo because humans are mammals and embryos are used for cloning. ${ }^{17}$ Nevertheless, at least one commentator claims that the Thirteenth Amendment prohibits human-embryo patents. ${ }^{18}$ For the Thirteenth Amendment to prohibit human-embryo patents, the Amendment must apply to human embryos and preclude the type of relationship that exists between a patent holder and a patented human embryo.

This Comment argues that the Thirteenth Amendment does not apply to human embryos, and even if it did, the relationship between patent holder and human embryo does not violate the Thirteenth Amendment's guarantee of freedom. In order to provide sufficient context to resolve these two major issues, Part II provides background regarding the human embryo's biological and legal significance in addition to a discussion of Thirteenth Amendment jurisprudence. Part III.A argues that because slavery only indirectly affected unborn life and, given the current limited legal rights of the human embryo, the Thirteenth Amendment does not apply to human embryos. Part III.B discusses how the Supreme Court's interpretation of "involuntary servitude," as used in the Amendment, cannot possibly apply to the human embryo based upon the Court's language. Part III.C compares the property interest associated with a patent to the relationship between slaveholder and slave, and ultimately concludes that human-embryo patents are not "akin to African slavery." Finally, Part III.D suggests several practical and policy justifications for not reading the Thirteenth Amendment to prohibit human-embryo patents.

16. John Miller, Note, A Call to Legal Arms: Bringing Embryonic Stem Cell Therapies to Market, 13 ALB. L.J. SCI. \& TECH. 555, 561-62 (2003). In 1998, U.S. Patent No. 5,843,780 was issued regarding a specific protocol for isolation of human embryonic stem cells, and in 2001, U.S. Patent No. 6,200,806 was issued over human stem cells "exclud[ing] others from making, using, selling, or importing human embryonic stem cells throughout the United States." Id.

17. See Justin Gillis, A New Call for Cloning Policy, WASH. Post, May 17, 2002, at A12; see also Esther Slater McDonald, Note, Patenting Human Life and the Rebirth of the Thirteenth Amendment, 78 Notre Dame L. Rev. 1359, 1361-62 n.14 (2003) (stating that other patents regarding cloning specifically exclude human clones; however, this patent makes no such explicit exclusion).

18. See McDonald, supra note 17, at 1386-87 (concluding that the Thirteenth Amendment precludes human-embryo patents). 


\section{BACKGROUND}

\section{A. Patenting Human Life and the Rebirth of the Thirteenth Amendment}

Esther McDonald argues that the Thirteenth Amendment is a legal barrier that prevents inventors from patenting human-embryo technologies. ${ }^{19}$ Her argument is that the Framers intended the Thirteenth Amendment to apply to human embryos by implicitly adopting the public opinion of the time, which was that the embryo deserved the utmost respect of a human being. ${ }^{20}$ She further claims that the Thirteenth Amendment ended property ownership of human beings, and therefore inventors should not be able to patent human embryos because a humanembryo patent would give the patent holder a property interest in a human being. ${ }^{21}$

McDonald opines: "history provides no support . . . that the framers intended to define "human being"' in a way to exclude human embryos because "[n]o relevant sources-neither public commentary, congressional debates, nor federal jurisprudence-suggest that the framers determined to alter the definition of human being from its scientific meaning." 22 According to McDonald, near the time the Amendment was enacted, physicians and the general public agreed the scientific definition of "human-being" included "prenatal human beings." 23 She notes that one physician wrote a book declaring life's beginnings upon formation of the embryonic stem cell, and another physician "instructed Harvard's Medical College on the humanity of the embryo, describing the embryo as 'a human being' from 'the moment an embryo enters the uterus a microscopic speck.", 24 McDonald also relies upon abortion literature of the time by commenting that various

19. Id.; see also Aaron Zitner, Patently Provoking a Debate, L.A. Times, May 12, 2002, at A1 (stating "the patent office argues that human embryos are equivalent to human beings, which puts them beyond the reach of patent claims" and "[a]lthough Congress has never spoken directly on the subject, the patent office says it infers the ban on these patents from such doctrines as the 13th Amendment ban of slavery").

20. See McDonald, supra note 17, at 1376-81 (arguing that the Framers adopted the Thirteenth Amendment with the then-current understanding that the human embryo was a "human being").

21. See id. at 1382-85 (arguing that a negative property right violates the Thirteenth Amendment's prohibition of "chattelism," the idea of man owning man as property).

22. See id. at 1376 (highlighting that others who argue "that the Thirteenth Amendment does not apply to human embryos" do not base their argument on the premise "that embryos are not human beings").

23. Id.; see also Zitner, supra note 19 ("[T]he patent office argues that human embryos are equivalent to human beings, which puts them beyond the reach of patent claims.").

24. See McDonald, supra note 17, at 1377 (noting that another medical professor described the embryo as a human being independent from its mother). 
physicians and professors criticized abortion as "destruction of a life.", 25 In addition, McDonald asserts that feminists viewed the destruction of prenatal humans as contrary to the human rights of the embryo. ${ }^{26}$ She notes that feminists distinguished the use of contraceptives from embryo destruction "because [contraception] merely prevent[s] the creation of a human being," but once the embryo is conceived it should have every right to exist. ${ }^{27}$ Essentially, McDonald argues that it was the intent of the legislators to incorporate the human embryo within the scope of the Thirteenth Amendment because the legislators did not alter the thenexisting scientific and public understanding of the human embryo as a human being. ${ }^{28}$

McDonald argues further that the Declaration of Independence, Constitution, and political philosophy of the time demonstrate that the Thirteenth Amendment was intended to abolish property ownership of human beings. ${ }^{29}$ She explains that "[b]y 1865, 'virtually everyone . . . understood slavery as chattelism,' the idea that human beings can be property," ${ }^{30}$ including the Supreme Court, which declared that the Thirteenth Amendment abolished chattelism and protected the individual freedom of human beings. ${ }^{31}$ Although not all congressmen agreed that the Amendment guaranteed civil liberties as well as individual freedom, even congressmen holding this narrow view agreed that the Amendment ended chattelism and the idea of treating human beings as property. ${ }^{32}$ And this is exactly why McDonald emphasizes that "[a] patent bestows upon the patent holder a property right in the patented invention," because the right to exclude others from making, using, or selling the invention is essential to owning property and therefore violates the Thirteenth Amendment's abolition of owning human beings as property. ${ }^{33}$ McDonald summarizes that "[a]t a minimum, the

25. See id. at 1378-80 (quoting medical doctors and professors as agreeing upon the fact that a human embryo exists as a human being and noting other groups, such as feminists, recognize the embryo as human life). To bolster her point, McDonald remarks that "[i]n 1859, the [American Medical Association (AMA)] issued a Report on Criminal Abortion" and "[t]he passage of legislation criminalizing abortion, particularly in response to the AMA's campaign, demonstrates that in the 1800 s the national public regarded the embryo as a human being." Id.

26. Id. at $1380-81$.

27. $I d$. at 1380 .

28. Id. at 1381.

29. Id. at $1371-74$.

30. Id. at 1371-72 (internal footnotes omitted).

31. Id. at $1374-75$.

32. Id. at 1374. Congress responded to this possible narrow interpretation of the Thirteenth Amendment by ratifying the Fourteenth Amendment to protect the civil liberties of all citizens. Id.

33. Id. at $1384,1386$. 
Amendment abolished chattelism, or property interest in a human being, ${ }^{34}$ and human-embryo patents violate the Amendment by giving the patent holder a property interest in a human being. ${ }^{35}$

A proper analysis of this issue, however, requires consideration of modern scientific and legal approaches for understanding the human embryo and a thorough search for defining exactly what the Thirteenth Amendment abolished. McDonald's argument oversimplifies both whether the Amendment even applies to human embryos and the type of property ownership prohibited by the Amendment. This Comment argues that the human embryo does not warrant Thirteenth Amendment protection; however, even if the Thirteenth Amendment applies to human embryos, it still does not prevent the type of relationship created by a patent.

\section{B. The Human Embryo's Biological and Legal Significance}

Rather than conclude that a human embryo is a human being deserving complete respect, science and the law respect only the potential of the human embryo to develop into a human individual. A modern scientific approach focuses on whether the human embryo represents "life-in-general" 36 or "life in a special sense." 37 Essentially, all life on earth is "life-in-general," such as bacteria, plants, insects, and animals; however, as human beings, we distinguish ourselves as more "special" than other living organisms based upon the "ability to feel and express a range of genuine human emotions and, most important, [the] attainment of the uniquely human condition of reflective selfawareness. ${ }^{38}$ Despite this distinction, the slow and continuous nature of human development makes it difficult for scholars to pinpoint the exact moment in human development when an individual becomes "special.,"39

\footnotetext{
34. Id. at 1373 .

35. Id. at 1386 .

36. See LeE SiLver, Remaking Eden 21 (2002) ("Life-in-general can exist not only in the absence of consciousness, but in the absence of any kind of neurological activity whatsoever. Examples of life-in-general abound on earth and include millions of different species of microbes, fungi, and plants.").

37. See id. at 24 (defining "life in a special sense" as the "very separate meaning that we give to conscious life, in its human form"). McDonald's argument and court cases use the phrase "human being" in the same way as biologists use the phrase "life in a special sense" to emphasize the unique qualities ascribed to a fully functioning adult individual. The phrases are used interchangeably in this Comment for purposes of convenience and clarity.

38. Id. at 25 .

39. See id. at 41-56 (discussing embryo formation and various views on the amount of respect a human embryo deserves); see also C.R. Austin, HumAn EMBryos: THE DeBATE ON Assisted
} 
Some scholars argue that the embryo is "life-in-general," yet others argue that it is "life in a special sense." 40 Part of the confusion contributing to the debate over the embryo's status is the fact that the embryonic phase of development is immediately preceded by human "life-in-general," and immediately followed by human "life in a special sense."

Before embryonic formation, one's "life-in-general" forms inside his or her mother and father when the mother and father themselves are at the embryonic stage. ${ }^{41}$ Cells known as primordial germ cells "migrat[e] through the tissues of the early embryo" of one's mother and father and eventually develop into egg or sperm cells. ${ }^{42}$ The egg and sperm cells produced by the mother and father cannot develop into a human individual by themselves because each only contains half of the necessary genetic information. ${ }^{43}$ However, scholars note that the egg and sperm are important phases of human development just like the embryo. $^{44}$ But egg and sperm cells have never been generally accepted as "special," given their inability to express human emotions or become self-aware, not to mention that further human development is speculative at best, given their lack of a complete genetic makeup necessary for development. ${ }^{45}$

The human embryo is different from egg and sperm cells because it has the genetic tools for further development, yet the embryo lacks the ability to express emotions or self-awareness. Upon fertilization of the egg by the sperm, known as conception, ${ }^{46}$ the egg and sperm combine their genetic information resulting in the requisite amount of genetic code for further development. ${ }^{47}$ Conception is a popular phase for

REPRODUCTION (1989), reprinted in BARRY R. FurRow ET AL., BIOETHICS: HEALTH CARE LAW AND ETHICS 36-39 (5th ed. 2004) (discussing the formation of the human embryo).

40. See SILVER, supra note 36, at 21-26 (coining the phrases "life-in-general" and "life in a special sense"); AUSTIN, supra note 39, at 36 (describing the competing views on the human embryo by showing how some scholars believe conception is the focal point for when human life becomes "special" while others do not).

41. See SILVER, supra note 36 , at $41-47$ (describing the events before and after conception); AUSTIN, supra note 39, at 36-39 (same).

42. AUSTIN, supra note 39 , at 37 .

43. See SILVER, supra note 36, at 42 (noting that one pair of chromosomes comes from the mother and the other comes from the father resulting in twenty-three pairs of chromosomes); $c f$. AUSTIN, supra note 39, at 36 (noting that fertilization is the point at which some begin to refer to human life as a human individual).

44. See, e.g., SILVER, supra note 36, at 41-43 (describing the egg and sperm); AUSTIN, supra note 39 , at 36 (noting that the embryo is just a collection of undifferentiated cells).

45. See SILVER, supra note 36, at 30-40 (discussing the origins of life on earth).

46. Neil A. CAmpBell \& JANe B. Reece, Biology 978 (7th ed. 2005).

47. See SILVER, supra note 36 , at 45 (describing that fertilization is complete when the chromosomes from the sperm and egg commingle for the first time). 
focusing on the beginning of one's "life in a special sense" because for some it represents when one becomes an individual, ${ }^{48}$ and it is the first point at which all of the genetic pieces are in place. ${ }^{49}$ The result of conception is a zygote, which begins dividing about twenty-four hours after fertilization. ${ }^{50}$ The zygotic cells continue to divide to form a collection of cells known as the embryo. ${ }^{51}$ The cells comprising the embryo are undifferentiated stem cells, meaning that they have no specific function, and notably, "there are no nerve cells formed during the first week after fertilization," 52 meaning that an embryo lacks any capacity to have thoughts or feelings. ${ }^{53}$ Although the embryo is different from earlier phases of human life based on its more realized potential for human development, it still lacks the qualities we ascribe to "special" human life absent a nervous system. ${ }^{54}$

Because the human embryo has the requisite genetic tools for developing into "life in a special sense" and due to its presence at an early stage of human development, the modern scientific understanding of the human embryo has allowed for the development of unique technologies. Technologies such as in vitro fertilization, embryo screening, cloning, and genetic manipulation take advantage of the embryo's unique biology. In vitro fertilization is an assisted reproductive technology that can help a woman become pregnant despite problems of infertility. ${ }^{55}$ Hormonal stimulation allows for the surgical begins).

48. See AUSTIN, supra note 39, at 36 (discussing various notions of when a person's life

49. Id. But see SILVER, supra note 36, at 44-45 (describing how fertilization is not complete until the zygote divides for the first time because until then, there is no mingling of the genetic material of sperm and egg).

50. CAMPBELL \& REECE, supra note 46, at 978.

51. See SILVER, supra note 36 , at 45-46 (discussing usage of the term "embryo"). The embryo secretes hormones indicating its presence within the mother. CAMPBELL \& REECE, supra note 46, at 978. Without secretion of a particular embryonic hormone, the mother will lose the embryo, id., and actually, "one-third of all pregnancies, often before the woman is even aware she is pregnant," end in spontaneous abortion or miscarriage. Id.

52. SILVER, supra note 36 , at 52.

53. See id. ("[F]eelings, of any sort, cannot arise in the absence of a functional nervous system . ...").

54. See CAMPBELL \& REECE, supra note 46, at 979 (explaining the stages of embryo growth and development). During formation, the embryo begins to implant itself into the endometrium for further development, and this is when the first trimester of pregnancy begins. Id. It is during the first trimester when the embryo begins developing body organs. Id. "By the end of the eighth week, all the major structures of the adult are present in rudimentary form," and the embryo becomes known as the fetus. Id. The fetus grows and becomes active during the second trimester and the pregnancy becomes obvious. Id. The third trimester consists of more growth until reproductive mechanisms trigger the beginning of labor and the postnatal life of the child. Id. at 981 .

55. See id. at 984 (describing the in vitro fertilization process). 
removal of eggs from the woman's ovaries, ${ }^{56}$ and then the sperm fertilizes the egg in a culture dish where the resulting cell incubates for a few days and develops into an embryo. ${ }^{57}$ Once the embryo divides into the eight-cell stage, it is implanted in the woman's uterus where development continues as in traditional pregnancies. ${ }^{58}$ In vitro fertilization is an assisted reproduction method, whereas embryo screening involves "testing" an embryo for desired characteristics. "A9 "At the eight-cell stage of [embryonic] development, one cell is removed . . . without causing lasting harm, for testing." ${ }^{.60}$ Embryo screening allows for the testing of any embryo for things such as chromosomal abnormalities, gender, and matches for siblings who need transplants. ${ }^{61}$ Rather than test an embryo for its genetic information, the process of cloning allows for the creation of an embryo that has the exact genetic information as the genetic donor. ${ }^{62}$ The process involves removing an egg cell's nucleus, which contains the genetic information, and replacing it with the nucleus of an adult cell. ${ }^{63}$ Nuclear transfer replaces the natural process of sperm-egg fertilization because the nucleus of an adult cell contains all forty-six chromosomes, therefore providing the requisite amount of genetic information for continued development. ${ }^{64}$ And finally,

56. Id.

57. Id.

58. Id. In vitro fertilization can cost thousands of dollars, but the process has resulted in thousands of healthy children with very few irregularities. Id. Despite successes, in vitro fertilization is not a flawless process. Id. One clinic reported that $50-70 \%$ of attempts resulted in pregnancies and $40-66 \%$ resulted in live births in 2004. Advanced Fertility Center of Chicago, http://www.advancedfertility.com/ivf\%20pregnancy\%20live\%20birth\%20rates\%202004.htm (last visited Mar. 13, 2007).

59. See Rick Weiss, Increasingly, Couples Use Embryo Screening, WASH. Post, Sept. 21, 2006, at A02 ("Pre-implantation genetic diagnosis, or PGD, starts with the creation of a 'test tube' embryo. At the eight-cell stage of development, one cell is removed, apparently without causing lasting harm, for testing.").

60. Id. The cells remain incredibly similar to one another at the eight-cell stage, so the testing of one cell reveals information about all of the remaining cells. See CAMPBELL \& REECE, supra note 46 , at 414 (describing that cell differentiation results in cell specialization of structure and function to form tissues and organs).

61. Weiss, supra note 59. Once an embryo undergoes screening and is confirmed to have the desired characteristics, it may be implanted in a woman as described for in vitro fertilization. CAMPBELl \& REECE, supra note 46, at 984 . This allows prospective parents to choose which embryo is best suited for their desires. See Weiss, supra note 59 (describing the possibilities provided by embryo screening). However, twenty-one percent of clinics were aware of errors made during the process, "including children born with the problem that was supposed to have been screened out." Id.

62. See CAMPBELl \& REECE, supra note 46, at 416 (describing reproductive cloning).

63. See id. at 416-17 (noting that reproductive cloning has been successful for sheep, mice, cats, cows, horses, and pigs).

64. See id. at 219 (noting that all nonreproductive body cells "each contain 46 chromosomes made up of two sets of 23, one set inherited from each parent"); SILVER, supra note 36, at 51 (noting 
genetic modification is a process resulting in an organism's artificial acquisition, removal, or replacement of "one or more genes from the same or another species" allowing for predetermination of the organism's genetic design. ${ }^{65}$ As demonstrated by these four technologies, the uniqueness of human life at the embryonic stage allows for unparalleled opportunities for the application and advancement of scientific theory.

Understanding of the human embryo and technological processes associated with it suggest that, at a minimum, the embryo is "life-ingeneral" with potential for development into "life in a special sense." One scholar has difficulty defining the embryo as "special" because the embryo is only one-fifth of a millimeter long, lacks consciousness, cellular diversity, and mobility, and is indistinguishable from its surroundings. ${ }^{67}$ In other words, the embryo "is in no way a 'body' and it does not bear the faintest resemblance to a human being-and the soul cannot enter yet, for the [embryo] may yet divide in the process of twinning, and the soul being unique is indivisible."68 However, the Geneva Convention Code of Medical Ethics suggests that the embryo is "special" by acknowledging that physicians "“will maintain the utmost respect for human life from the time of conception." 69 Despite disagreement on whether the human embryo represents mere potential or

that there is no conception in the cloning process because the nucleus donated by the adult cell provides the requisite amount of genetic material). The resulting egg cell can then be implanted into a female's uterus for further development. CAMPBELl \& REECE, supra note 46, at 416. In 1997, Scottish researchers cloned a lamb named Dolly by taking cells from the mammary glands of one lamb and fusing them with the nucleus-free egg of another lamb. Tests proved that the cloned lamb had identical chromosomes as that of the nucleus donor. Although the chromosomes of a clone are identical to that of the nucleus donor, cloned animals do not necessarily look or behave identically to their nucleus donor. For instance, a herd of cloned cows from the same nucleus donor consisted of dominant and submissive cows. Id. Moreover, a cloned cat had a different colored and patterned coat than her nucleus donor. Id. at 416-17. As with in vitro fertilization and embryo screening, reproductive cloning is not a flawless procedure. Id. A cloned sheep "suffered complications from a lung disease usually seen in much older sheep and was euthanized." Id. at 416 . "Cloned mice . . are prone to obesity, pneumonia, liver failure, and premature death." Id. at 417 . In fact, cloned embryos are more likely than not to suffer complications in their development towards birth Reproductive cloning of humans is currently speculative, but Korean researchers have already cloned embryos and allowed the resulting cells to divide. The cells were not allowed to divide any further, but these results are a major step towards the successful cloning of a human being. Id.

65. CAMPBELL \& REECE, supra note 46, at 407. Salmon have been genetically modified to grow faster by adding a more active growth hormone gene to their DNA. Id. Most genetic modification concerns plants, but recent advances in biotechnology, such as the complete mapping of the human genome, and success with salmon suggest the possible genetic modification of human beings. Id. at 407-08.

66. See Austin, supra note 39 , at 36-39 (discussing when a person's life actually begins).

67. Id. at 38 .

68. Id.

69. Id. at 36 . 
is actually "special," some areas of the law afford the human embryo at least limited protection based upon its potential.

The law affords human embryos "respect because of their potential for human life."70 Recognition of limited legal rights for the human embryo appears in custody suits, abortion cases, and criminal and wrongful death actions. ${ }^{71}$ In Davis v. Davis, the Supreme Court of Tennessee expressly acknowledged that human embryos are not "persons" or "property" and deserve "special respect because of their potential for human development.", In Roe v. Wade, the Supreme Court of the United States noted that the government has an "important and legitimate interest in preserving and protecting the potentiality of human life." ${ }^{, 73}$ And in Planned Parenthood v. Casey, ${ }^{74}$ the current legal standard governing the embryo's rights in the context of abortion, the Supreme Court of the United States held that the government may regulate abortion so long as regulation does not place an undue burden on women seeking an abortion. ${ }^{75}$ The embryo's legal protection is thin, however, because it is not a legally recognized "person" deserving full constitutional rights. ${ }^{76}$ If the embryo was a "person," it would receive full constitutional protection and abortion would be murder. ${ }^{77}$ Although the embryo only has the right of government protection short of causing an undue burden for abortion, in some jurisdictions, in contexts other than abortion, killing an embryo is considered murder.

Despite the extremely thin legal rights of the embryo in abortion law, the criminal and common law in some jurisdictions protects embryos when someone other than the woman carrying the embryo causes its death, when a pregnant woman kills in defense of the unborn child's life, or when a child born alive is injured as a result of actions before birth. ${ }^{78}$

70. Davis v. Davis, 842 S.W.2d 588, 597 (Tenn. 1992).

71. See FurRow ET AL., supra note 39, at 39-47 (discussing constitutional, statutory, and common law recognition of the beginnings of human life).

72. 842 S.W.2d at 597.

73. See Roe v. Wade, 410 U.S. 113, 162 (1973) (analyzing when the government's interest in preserving life is compelling enough to override a woman's right to abortion).

74. 505 U.S. 833 (1992).

75. Id. at 878; see also FURROW ET AL., supra note 39, at 41-42 (discussing Roe and legal rights guaranteed to the human embryo).

76. See Roe, 410 U.S. at 156-58 (concluding that the government's interest in human life is not compelling at the embryo stage of development).

77. See id. ("If this suggestion of personhood is established, the appellant's case, of course, collapses, for the fetus' right to life would then be guaranteed specifically by the Amendment.").

78. See FURROW ET AL., supra note 39, at 41-44 (discussing the rights of the human embryo in the criminal law and common law); Marguerite A. Driessen, Avoiding The Melissa Rowland Dilemma: Why Disobeying A Doctor Should Not Be A Crime, 10 Mich. ST. J. MED. \& LaW 1, 9-14 (2006) (recognizing several theories concerning the source of the rights of unborn children); see also 
At common law, the old rule was that recovery of damages was allowed "only if the decedent were born alive," but "[m]any courts now distinguish between a viable and a pre-viable fetus for purposes of recovery" ${ }^{\prime 79}$ because viability is the stage at which unborn life can survive outside the womb. ${ }^{80}$ However, some courts have gone so far as to allow damages for unborn life prior to viability. ${ }^{81}$ Whether or not viability is the point at which the law recognizes rights of the embryo, legal protection of the embryo does not necessarily rest on grounds that the embryo is "special" and deserving of full constitutional rights. ${ }^{82}$ Instead, the human embryo deserves legal respect "because of its potential to become a person ... [but] it should not be treated as a person[] because it has not yet developed the features of personhood, is not yet established as developmentally individual, and may never realize its biologic potential." ${ }^{\prime 3}$ In fact, one scholar notes that the legal rights of the unborn actually originate from the recognition of the rights of others in unborn children. ${ }^{84}$ Although legal respect for the human embryo is not the equivalent of full legal protection, the potential for human development

People v. Kurr, 654 N.W.2d 651, 653-54 (Mich. App. 2002) (allowing a pregnant woman to use the defense of "defense of another" as an excuse for a crime when the embryos' life is endangered by a third party); State v. Merrill, 450 N.W.2d 318, 323 (Minn. 1990) (holding the defendant liable for the death of a woman's unborn child despite the fact that the defendant did not know of the pregnancy).

79. See FURROW ET AL., supra note 39, at 44-45 (citing numerous jurisdictions). One common law court rejected the old rule because "the live birth requirement was an arbitrary line that served no purpose of the wrongful death and . . survival statute." Id. at 45 . "Today's holding merely makes it clear that the recovery afforded the estate of a stillborn is no different than the recovery afforded the estate of a child that dies within seconds of its release from its mother's womb." Amadio v. Levin, 501 A.2d 1085, 1089 (Pa. 1985). Some people have embraced this ruling because they claim "the fetus is . . . a full human being entitled to all protections accorded to all other human beings." FURROW ET AL., supra note 39, at 45. Those opposing the new rule have "argued that there was no genuine loss that was being compensated in such cases, and that the real reason for permitting the recovery was to allow plaintiffs a greater chance at a larger recovery." Id.

80. See Roe, 410 U.S. at 160 (noting that viability occurs at twenty-four weeks into the pregnancy, but may decrease in time as technology advances); AUSTIN, supra note 39, at 38 (approximating that viability is achieved at about twenty-four weeks into pregnancy).

81. See FURROW ET AL., supra note 39, at 46-47 (citing numerous cases allowing for recovery prior to viability and numerous cases not allowing recovery prior to viability).

82. See People v. Ford, 581 N.E.2d 1189, 1198 (Ill. App. Ct. 1991) (removing any distinction between viability and nonviability so that the homicide statute applied to any "unborn" entity). The court in People v. Ford notes that "whatever the entity within the mother's womb is called, ... [i.e., life-in-general or life in a special sense], because of the acts of the defendant," the entity no longer has a chance for development. See id. at 1201 (focusing on the fact that some sort of life existed, despite whether the entity was a "human being"). And although the use of deadly force is a valid defense to a charge of manslaughter, "the defense is available solely in the context of an assault against the mother ... [and] has not extended the protection of the criminal laws to embryos existing outside a woman's body, i.e., frozen embryos stored for future use." Kurr, 654 N.W.2d at 654 .

83. Davis v. Davis, 842 S.W.2d 588, 596 (Tenn. 1992).

84. Driessen, supra note 78 , at 9-14 (discussing the rights of the mother and the state in unborn children). 
should weigh heavily in determining whether a particular law applies to the human embryo.

\section{The Thirteenth Amendment}

For the Thirteenth Amendment to preclude human-embryo patents the Amendment must apply to human embryos and, if it applies, must adequately prevent the type of relationship created between the patent holder and human embryo. On its face, the scope of the Thirteenth Amendment's application is not abundantly clear. The Amendment is short and concise-" $[\mathrm{n}]$ either slavery nor involuntary servitude, except as a punishment for crime, whereof the party shall have been duly convicted, shall exist within the United States, or any place subject to their jurisdiction." ${ }^{85}$ The Amendment does not explicitly state to whom the Amendment applies or define "slavery" and "involuntary servitude."

\section{To Whom Does the Thirteenth Amendment Apply?}

In determining to whom the Thirteenth Amendment applies, it is helpful to address the historical context in which the Amendment was enacted and Supreme Court cases discussing its scope. Historical context suggests that the Framers never directly considered the effects of the Amendment upon prenatal life. Supreme Court cases addressing the issue discuss it in the context of race rather than distinguishing between prenatal and postnatal life. However, even if the Framers of the Thirteenth Amendment intended it to apply to the human embryo, a modern court would not adopt the 1865 understanding that the human embryo was a human being.

The social and political concerns surrounding the ratification of the Thirteenth Amendment highlight the turmoil created by the controversial status of African slavery at the time. ${ }^{86}$ "Slavery remained a haunting presence in national politics, and although often unspoken, it inspir[ed] many apprehensive glances over the shoulder." Jacksonian coalition supported slavery, but did so in a passive way in order to remain in good standing with their antislavery counterparts in the North. ${ }^{88}$ On the other hand, William Lloyd Garrison "set out to

85. U.S. CONST. amend. XIII, $\S 1$.

86. See Don E. Fehrenbacher, Slavery, Law, \& Politics: The Dred Scott Case in HISTORICAL PERSPECTIVE 56-63 (1981) (describing the political impact of slavery).

87. Id. at 56 .

88. Id. 
destroy slavery by direct, personal attack upon everyone associated with the institution and everyone who temporized with it." ${ }^{\text {9 }}$ The political struggle between pro- and antislavery groups resulted in "no southern abolition societies remain[ing] in existence, and the defense of slavery as a positive good ... replac[ed] the old argument that it was an unfortunate but inescapable legacy. More and more, southerners regarded every attack on the institution as an impeachment of their decency, virtue, and honor." $"$ The overwhelming social and political struggle regarding African slavery suggests that the effects of the Thirteenth Amendment upon prenatal life were never fully considered.

Although the express intent of the Framers regarding prenatal life is not clear based upon the politics of the time, the Supreme Court has implied the Framers' intent for defining the situations for which the Thirteenth Amendment applies. ${ }^{91}$ Focusing on the "pervading spirit" for determining the range of circumstances intended by the Framers, ${ }^{92}$ the Court makes clear that

in any fair and just construction of any section or phrase of these amendments, it is necessary to look to the purpose which we have said was the pervading spirit ...., the evil which they were designed to remedy, and the process of continued addition to the Constitution, until that purpose was supposed to be accomplished, as far as constitutional law can accomplish it. ${ }^{93}$

The Slaughter-House Court says the "pervading spirit" of the Amendment is to prohibit all types of slavery "akin to African slavery." In other words, "while negro slavery alone was in the mind of the Congress which proposed the thirteenth article, it forbids any other kind of slavery, now or hereafter." 95

The Supreme Court has looked to the "pervading spirit" for determining to whom the Thirteenth Amendment applies. Notably, it is

89. Id.

90. Id. at 57 .

91. See United States v. Kozminski, 487 U.S. 931, 941-42 (1988) (interpreting two criminal statutes' use of "involuntary servitude" by using the same interpretation used for the Thirteenth Amendment).

92. Id.; see also Slaughter-House Cases, 83 U.S. 36, 72 (1872) (explaining the Court's approach for interpreting the Amendment); Akhil Reed Amar \& Daniel Widawsky, Child Abuse as Slavery: A Thirteenth Amendment Response to Deshaney, 105 HARV. L. REV. 1359, 1368 (1992) (same).

93. Slaughter-House Cases, 83 U.S. at 72

94. Id.; Amar \& Widawsky, supra note 92, at 1369 (quoting Kozminski, 487 U.S. at 942).

95. Slaughter-House Cases, 83 U.S. at 72. 
the Court and not the Framers that use the phrase "human being," and they do so to emphasize the Thirteenth Amendment's impact beyond the African race to preclude the enslaving of members of any race. ${ }^{96}$ Although the Slaughter-House Court explicitly states that the Thirteenth Amendment applies to "human beings," it never discusses prenatal life nor makes a distinction between human "life-in-general" and human "life in a special sense." 97 The Framers and the Court have never squarely addressed the Amendment's application to the human embryo, but even if the Framers believed that the human embryo was a human being, a modern court should not adopt the 1865 understanding of the human embryo as a human being.

Although the actual text of the Constitution remains static over time, constitutional interpretation continues to develop. McDonald's reliance upon reproduction literature and abortion debates to show "that the framers understood 'human being' to include pre-natal human beings" fails to address whether modern courts would agree with the Framers and implement their understanding of "human being" into modern law. ${ }^{98}$ Because the Framers never squarely considered prenatal life, it is unclear whether the Framers and the Court set a static legal definition of human being based upon 1865 scientific theory. Instead, the legal definition should develop along with the scientific definition. Fourteenth Amendment Supreme Court cases concerning equal protection and abortion suggest that a court would adopt a modern understanding of scientific theory.

For example, the Supreme Court reevaluated and changed its interpretation of Equal Protection under the Fourteenth Amendment in response to changes in the education system. ${ }^{99}$ Prior to Brown v. Board of Education, ${ }^{100}$ the Supreme Court interpreted the Fourteenth Amendment's Equal Protection clause to require separate facilities for African-American and white citizens. ${ }^{101}$ The reasoning was that equality

96. See id. at 69 (inferring that the Thirteenth Amendment "can only apply to human beings"). "The word servitude is of larger meaning than slavery, as the latter is popularly understood in this country, and the obvious purpose was to forbid all shades and conditions of African slavery." Id.

97. Id. Another Supreme Court case using the phrase "human being" in the context of the Thirteenth Amendment also fails to acknowledge prenatal life. See Hodges v. United States, 203 U.S. 1, 26 (1906) (referring to human beings of African descent).

98. McDonald, supra note 17, at 1370-81.

99. See generally Brown v. Bd. of Educ., 387 U.S. 483 (1954) (reinterpreting the Fourteenth Amendment's equal protection guarantee).

100. Id.

101. See generally Plessy v. Ferguson, 163 U.S. 537 (1896) (interpreting "separate but equal" under the Fourteenth Amendment's equal protection guarantee to only require separate facilities of equal quality for each race). 
could be achieved despite segregation of the races. ${ }^{102}$ Although the facts indicated that there was equality between the black and white schools regarding physical and educational needs, the Court held that "[s]eparate educational facilities are inherently unequal."103 The Court explicitly acknowledged that "[i]n approaching this problem, [it] cannot turn the clock back to 1868 when the Amendment was adopted, or even to 1896 when Plessy v. Ferguson was decided. [It] must consider public education in the light of its full development and its present place in American life throughout the Nation."104

Similar reasoning was used by the Supreme Court for declining to define human life as becoming "special" at the moment of conception. The Court rejected the idea that human beings are formed upon conception and instead adopted a modern understanding of human development by refraining from defining exactly when human life becomes "special." 105 The Court reasoned that it was not more inclined to define "life" than science, theology, or philosophy, which all fail to adopt a unified, modern definition. ${ }^{106}$ Recognizing the difficulty in determining when human life becomes "special," the Court expressly acknowledged that formation of a human being is a process and not an event. ${ }^{107}$ The Court highlighted that "[a]t the heart of liberty is the right to define one's own concept of existence, of meaning, of the universe, and of the mystery of human life." 108 The drastic change in scientific understanding since 1865 suggests, at a minimum, that laws will not apply to human embryos based on the theory that the human embryo is "life in a special sense."

102. See id. at 550-52 (denying that desegregation was necessary for the Fourteenth Amendment's equal protection guarantee).

103. Brown, 387 U.S. at 495 . The Court addressed the validity of "separate but equal" in public schools under a law denying black children enrollment in a white school. Id. at 486 .

104. Id. at 492-93. In 1868, private groups were responsible for the education of white children, whereas the education of black children was practically nonexistent. Id. However, at the time of Brown, education had become "a principal instrument in awakening the child to cultural values, in preparing him for later professional training, and in helping him to adjust normally to his environment .... [I]t is doubtful that any child may reasonably be expected to succeed in life if he is denied the opportunity of an education." Id. at 493.

105. See Roe v. Wade, 410 U.S. 113, 160-62 (rejecting any view that human life becomes "special" at fertilization).

106. Id. at 159 .

107. Id. at $133,160-61$

108. See Planned Parenthood v. Casey, 505 U.S. 833, 860-73 (1992) (describing advances in health care and the concept of fetus viability). 


\section{What Did the Thirteenth Amendment End?}

Courts, Framers, and scholars have repeatedly referred to African slaves as property, and it is clear that the Thirteenth Amendment ended the institution of African slavery. But a closer look at the slaveholderslave relationship reveals a complexity beyond mere property ownership. $^{109}$ At least one slave state, Tennessee, expressly acknowledged the slave as "thinking property" and recognized agency aspects of slavery. ${ }^{110}$ And on the federal level, the Supreme Court of the United States implied an agency relationship through its interpretation of "involuntary servitude."

a. The Supreme Court of Tennessee: Agency Aspects of the Slaveholder-Slave Relationship

The Supreme Court of Tennessee was confronted with several situations "revealing the juristic limitations of treating a slave as ordinary chattel." "The slave's humanity as "thinking property" actually "conferred particular value on slave property . . . because where a 'property in intellectual and moral and social qualities, in skill, in fidelity, and in gratitude,' was concerned, the 'market value' was not 'adequate remedy." "113 Troublesome areas of the law for treating slaves as ordinary property were the laws of manumission, "vicarious liability of slaveholders for wrongs committed by slaves,"114 and "liability for conversion of a slave's services and death of a slave."

The laws of manumission "demonstrate[d] . . . that the Tennessee Court was generous and sympathetic, sensitive to the humanity of the slave," in addition to revealing the plight of treating humans as legal

109. See Jacob I. Corré, Thinking Property at Memphis: An Application of Watson, in SLAVERY \& THE LAW 437, 437-38 (Paul Finkelman ed., 1997) (describing the special value of slaves versus chattel or other property); Arthur Howington, "A Property of Special and Peculiar Value": The Tennessee Supreme Court and the Law of Manumission, 44 TENN. HIST. Q. 302, 302 (1985), reprinted in ARTICLES ON AMERICAN SLAVERY: LAW, THE CONSTITUTION, AND SLAVERY 210, 210 (Paul Finkelman ed., 1989) (same).

110. Corré, supra note 109, at 437.

111. United States v. Kozminski, 487 U.S. 931,942 (1988).

112. See Corré, supra note 109 , at 438 (discussing cases where property law was inadequate for addressing the slaveholder-slave relationship).

113. Howington, supra note 109, at 302, reprinted in ARTICLES ON AMERICAN SLAVERY: LAW, THE CONSTITUTION, AND SLAVERY 210, 210 (Paul Finkelman ed., 1989).

114. See Corré, supra note 109, at 439-44 (discussing trouble faced by Tennessee regarding slaves and vicarious liability).

115. See id. at 444-47 (discussing trouble faced by Tennessee regarding conversion of a slave's services and death of a slave). 
property. ${ }^{116}$ Manumission was the emancipation of a slave, which could take effect immediately or upon the occurrence of a later event. ${ }^{117}$ In order to recognize emancipation, the court had to acknowledge the slave's right to freedom, which "was meaningless unless he or she could protect it." 118 However, here exists " "one of the most troublesome questions' in the law of emancipation, 'whether children born of a female slave who had been promised freedom were entitled to the same benefit." 119 Concluding that "emancipation should be 'liberally construed in favor of liberty," the court held that although emancipation takes effect at a later date, the soon-to-be-free slave has a "present right to freedom," and "[a] child born to such a person was born free.", Nevertheless, the Supreme Court of Tennessee denied a child born to such a person his freedom when the child was sold into Alabama and escaped back to Tennessee. ${ }^{121}$ The court admitted that the child was "free-born" but upheld the Alabama slaveholder's interest based on fugitive slave laws. ${ }^{122}$ Despite the outcome of this case, the laws of manumission definitely highlight the legal system's trouble with treating the slave as ordinary property.

The peculiar situation of the slave as "thinking property" pressed the courts to consider agency law for resolving certain disputes.

A vision of the owner-slave relationship grounded on principles of agency had the virtue of implying a realistic account of the slave's mental capacities, but it could not accommodate the slave's lack of legal rights. A model of the relationship based on notions of property . . . made sense of the slave's personal status in legal terms, but it could not be coherently adopted in cases where the slave had exercised his

116. Howington, supra note 109, at 307, reprinted in ARTICLES ON AMERICAN SLAVERY: LAW, THE CONSTITUTION, AND SLAVERY 210, 215 (Paul Finkelman ed., 1989).

117. See id. at 303-07, reprinted in ARTICles ON AMERICAN SLAVERY: LAW, THE CONSTITUTION, AND SLAVERY 210, 211-15 (Paul Finkelman ed., 1989) (discussing laws of manumission).

118. Id. at 307, reprinted in ARTICLES ON AMERICAN SLAVERY: LAW, THE CONSTITUTION, AND SLAVERY 210, 215 (Paul Finkelman ed., 1989).

119. Id. at 306, reprinted in ARTICLES ON AMERICAN SLAVERY: LAW, THE CONSTITUTION, AND SLAVERY 210, 214 (Paul Finkelman ed., 1989).

120. Id., reprinted in ARTiCles on AMERICAN SLAVERY: LAW, THE CONSTITUTION, AND SLAVERY 210, 214 (Paul Finkelman ed., 1989) (quoting Harris v. Clarissa, 14 Tenn. 164-65 (1834)).

121. Id. at 307, reprinted in ARTICLES ON AMERICAN SLAVERY: LAW, THE CONSTITUTION, AND SLAVERY 210, 215 (Paul Finkelman ed., 1989) (citing Sidney v. White, 33 Tenn. (1 Sneed) 91 (1853)).

122. Id. 
rational capacities in a manner that seemed significant from a moral or juristic point of view. ${ }^{12}$

In Wright v. Weatherly, ${ }^{124}$ Wright's slave killed Weatherly's slave and Weatherly sued Wright to recover the value of his slave. ${ }^{125}$ The Supreme Court of Tennessee did not find Wright liable, but it is unclear on which legal theory the court based its opinion. ${ }^{126}$ To apply a property theory, the court would have to analogize the circumstances of this case to the property law governing domestic animals. ${ }^{127}$ Therefore, Wright would only be liable if he knew of his slave's propensity for violence. ${ }^{128}$ Conversely, liability would not exist under an agency theory if the slave committed the act willfully and without Wright's approval. ${ }^{129}$ Wright was not liable under either theory because he did not know of any violent propensity of his slave and the slave acted willfully without Wright's consent, although the court did not explain which theory it based its opinion. ${ }^{130}$ After Wright, "the Tennessee Supreme Court inclin[ed] toward an agency-based conception of the relationship between slaveholder and slave" and rejected a pure-property analogy. ${ }^{131}$

An analogy between slavery and agency also materialized in Jones $v$. Allen, ${ }^{132}$ a case involving the conversion of a slave's services. ${ }^{133}$ Allen's slave performed cornhusking work for another slaveholder, Jones, without the express permission of Allen, yet Jones had the impression that Allen had given implied permission. ${ }^{134}$ After performing the work and before returning home, Allen's slave was killed by an uninvited guest. ${ }^{135}$ Allen sued Jones for conversion and the death of his slave. ${ }^{136}$ Jones's counsel argued a pure agency theory for absolving Jones of any liability based upon the custom of implied permission of another

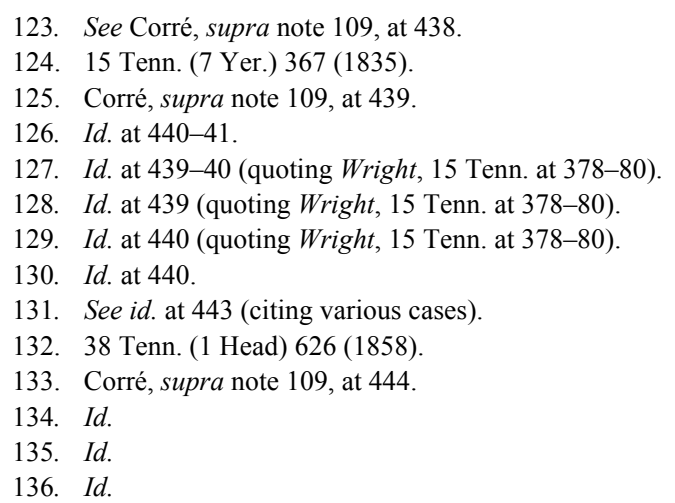


slaveholder for his slave's cornhusking services. ${ }^{137}$ However, the Supreme Court of Tennessee "avoided passing on the broadest implications of the pure agency theory put forth by Jones' counsel," and instead found Jones not liable "by reading the law of . . . conversion extremely narrowly." 138 Although neither the vicarious liability nor the conversion cases resulted in the court's full embrace of agency law for governing these situations, the Supreme Court of Tennessee was forced away from pure property law and closer to that of agency for resolving disputes involving "thinking property." 139 Although the Supreme Court of Tennessee is only one court among many that adjudicated cases involving slaves, its struggle in applying pure property law to slaves suggests that the Thirteenth Amendment ended something more complex than mere property ownership of man.

\section{b. A Prohibition Against Compelled Agency Relationships}

The Supreme Court of the United States implies an agency relationship between slaveholder and slave based on its interpretation of "involuntary servitude."140 The Amendment has been interpreted to prevent " "those forms of compulsory labor akin to African slavery which in practical operation would tend to produce like undesirable results." "141 The Amendment ends both slavery and involuntary servitude, which have two different meanings. ${ }^{142}$ The word slavery is associated with "all shades and conditions of African slavery." "143 And involuntary servitude, at a minimum, prevents

servitude in which the victim is forced to work for the defendant by the use or threat of physical restraint or physical injury, or by the use or threat of coercion through law or the legal process. This definition encompasses those cases in which the defendant holds the victim in servitude by placing the victim in fear of such physical restraint or injury or legal coercion. ${ }^{144}$

\footnotetext{
137. Id. at 446 .

138. Id.

139. Id. at 447-48.

140. See United States v. Kozminski, 487 U.S. 931, 942 (1988) (recognizing the difficulty in defining the range of circumstances in which the Thirteenth Amendment applies).

141. Id. (citing Butler v. Perry, 240 U.S. 328, 332 (1916)).

142. Slaughter-House Cases, 83 U.S. 36, 90 (1872) (Field, J., dissenting).

143. Id. at 69 .

144. Kozminski, 487 U.S. at 952 (emphasis added).
} 
A court may also consider other forms of coercion, poor working conditions, and the victim's vulnerabilities in determining whether servitude was involuntary. ${ }^{145}$ Essentially, the Thirteenth Amendment "guarantees freedom from arbitrary domination" and ensures the individual's complete autonomy. ${ }^{146}$

The Thirteenth Amendment's scope extends beyond slavery and involuntary servitude via the Enabling Clause, which allows Congress to enact laws "'rationally' capable of classification as a 'badge' or 'incident' of slavery."147 Scholars have specifically argued that cloning forms a badge of slavery by creating a form of "genetic bondage," thus infringing the autonomy of children born as a result of cloning. ${ }^{148}$ Essentially, the argument relies upon genetic determinism, or the idea that " our fate is in our genes," to show the potentially harmful psychological effects resulting from expectations created by knowing one's genetic make-up. ${ }^{149}$ "If raised by the clone-parent, a clone-child could see what he or she has the potential to become" and "[h]aving insight into one's potential may cause enormous pressures to live up to expectations ... ., even more so than those generally experienced by children." 150 Clones, therefore, would not be as autonomous as nonclones because they would feel bound by expectation and restricted in making their own life decisions. ${ }^{151}$ Arguably, this creates a badge of slavery by infringing on "those fundamental rights which appertain to the essence of citizenship." 152 But as Elizabeth Foley concludes, "it is

145. Id

146. Alexander Tsesis, The Thirteenth Amendment And AMERiCAN Freedom 112 (2004).

147. See Elizabeth Price Foley, The Constitutional Implications of Human Cloning, 42 ARIZ. L. REV. 647, 667 (2000) (citing Jones v. Alfred H. Mayer Co. as the seminal case on the badges of slavery).

148. See Lori B. Andrews, Is There a Right to Clone? Constitutional Challenges to Bans on Human Cloning, 11 HARV. J.L. \& TECH. 643, 652-56, 668 (1998) (suggesting that the potential psychological and social harms associated with knowing one's genetic predispositions violates the Thirteenth Amendment); $c f$. Foley, supra note 147, at 666-70 (challenging the notion that cloning violates the Thirteenth Amendment's prohibition against "badges of slavery").

149. See Andrews, supra note 148, at 652-56 (quoting Watson, one of the scientists responsible for discovering DNA).

150. Am. Med. Ass'N, The ETHICS OF HumAn Cloning 5 (1998), available at http://www.amaassn.org/ama1/pub/upload/mm/369/report98.pdf.

151. See id. ("A sports star's clone-child unable to live up to these expectations could be dubbed a failure unable to capitalize on his or her genetic gift . . . . If a clone-child saw that he or she was likely to develop certain diseases or had failed at certain tasks, his or her undertakings might be bounded by what the clone-parent had done."); Andrews, supra note 148, at 654 ("We already limit parents' genetic foreknowledge of their children because we believe it will improperly influence their rearing practices.").

152. Civil Rights Cases, 109 U.S. 3, 22 (1883); see also 42 U.S.C. § 1982 (2000) (“All citizens of the United States shall have the same right, in every State and Territory, as is enjoyed by white 
unlikely that a law banning human cloning could be construed as an attempt by Congress to remove a stamp of inferiority based upon race" because clones would not constitute their own race. ${ }^{153}$ Aside from whether cloning constitutes a badge of slavery, the potential psychological implications of reproductive cloning, and for that matter, any genetic technology involving genetic knowledge, such as embryo screening and genetic manipulation, are important considerations for determining whether the Thirteenth Amendment's abolition of "involuntary servitude" applies in such circumstances.

Although the Amendment is a prohibition against infringing another's autonomy, the potential psychological effects of reproductive cloning do not violate the Court's interpretation of "involuntary servitude" because the Court has limited the ways in which one can be liable for violating another's autonomy, not to mention that a prohibition against mere psychological effects ignores the coercion and agency aspects previously considered by the Court. ${ }^{154}$ For example, the Court expressly rejected an argument that the Thirteenth Amendment prevents psychological coercion because inclusion of psychological coercion within the breadth of involuntary servitude would require courts to "depend entirely upon the victim's state of mind ... . [S] uch a view ... would provide almost no objective indication of the conduct or condition ... prohibit[ed], and thus would fail to provide fair notice to ordinary people who are required to conform." 155 Sure, one could argue that the act of cloning itself would provide an objective indication of the conduct or condition prohibited, however, reproductive cloning would not necessarily be the cause of unwanted psychological effects in every situation. Instead, children may experience negative psychological effects from environmental factors independent of cloning, such as poor parenting. And again, any potential negative psychological effects of reproductive cloning would be a result rather than a means for coercing labor.

In addition to rejecting psychological coercion, the Court rejects an argument that the Thirteenth Amendment precludes situations where slave-like conditions are actually achieved no matter the means for

citizens thereof to inherit, purchase, lease, sell, hold, and convey real and personal property."); Foley, supra note 147, at 667-68 (discussing the definition of "badges of slavery").

153. Foley, supra note 147, at 668 (refuting the argument that cloning violates any badge of slavery as contemplated by the Thirteenth Amendment).

154. See United States v. Kozminski, 487 U.S. 931, 949 (1988) (holding that psychological coercion, alone, does not violate the Thirteenth Amendment).

155. Id. 
achievement. ${ }^{156}$ The Court reasons that there are no objective criteria for determining slave-like conditions beyond physical and legal coercion. ${ }^{157}$ Because the Supreme Court interpreted "involuntary servitude" as ending compulsory labor achieved through means of physical or legal coercion, the potential psychological effects of cloning do not trigger Thirteenth Amendment protection. ${ }^{158}$ And although the Court never explicitly addressed an agency relationship between slaveholder and slave, its definition of "involuntary servitude" implies an agency relationship by preventing a compelled agency relationship. Cases heard by the Supreme Court of the United States and the Supreme Court of Tennessee demonstrate that the Thirteenth Amendment ended something more than property ownership of man by implicitly and explicitly relying on agency analogies for resolving disputes.

\section{ANALYSIS}

The Thirteenth Amendment does not preclude human-embryo patents because it does not apply to human embryos, and it ended something wholly different than the relationship between patent holder and invention. There are two major flaws with McDonald's argument claiming that human-embryo patents violate the Thirteenth Amendment. First, McDonald's argument illogically assumes that the Framers intended to include the human embryo and fails to consider how modern courts would address the issue. Second, McDonald's argument claims that the Thirteenth Amendment ended mere property ownership of human beings without considering the true nature of the slaveholderslave relationship. Because a human-embryo patent gives the patent holder a property interest in a human being, human-embryo patents would violate her pure property interpretation of the Amendment.

Contrary to McDonald's argument, the Thirteenth Amendment does not apply to human embryos because slavery only indirectly affected the unborn, and today the legal recognition of the embryo rests on respect for its developmental potential, which the spirit of the Thirteenth Amendment fails to capture. Furthermore, the Supreme Court's interpretation of "involuntary servitude" uses language that is inapplicable to the embryo, such as "coercion" and "labor." However, even if the Amendment applies to human embryos, the Thirteenth

\footnotetext{
156. Id. at 951 .

157. Id.

158. See id. at 942 (basing its interpretation on the "pervading spirit" of the Amendment's purpose of ending all slavery "akin to African slavery").
} 
Amendment prohibits relationships reminiscent of the slaveholder-slave relationship rather than human-embryo patents. Additionally, there are several practical and policy reasons for why the Thirteenth Amendment should not prohibit human-embryo patents.

\section{A. The Thirteenth Amendment Does Not Protect the Human Embryo from Patents}

1. Slavery's Indirect Influence on Human Embryos

The Thirteenth Amendment was not expressly intended to apply to human embryos. The Framers and courts have never expressly included the human embryo within the scope of the Amendment, and given the controversial status of the human embryo, it seems counterintuitive to conclude that any law applies to human embryos based upon implications of nonconsideration. Perhaps the Framers and courts failed to consider the effects of the Amendment on the human embryo because of slavery's indirect application to unborn life. The Supreme Court of Tennessee's cases involving manumission demonstrate that the unborn children of slaves were not considered slaves independent of their mothers in at least one slave state. If unborn children were slaves, then the Supreme Court of Tennessee would not have classified the unborn child based upon the status of its soon-to-be-free mother. Instead, a slaveholder would have been required to make a separate act of freedom for the child in addition to freeing the mother. Because the Tennessee court did not require a separate act of emancipation to account for the unborn child's freedom, slavery may have only indirectly affected the unborn by virtue of the mother being enslaved, which would explain the Framers' nonconsideration of the issue.

In fact, slavery indirectly included the unborn children of slaves by virtue of the fact that the mother was a slave. Upon ratification of the Thirteenth Amendment, a mother could no longer be a slave and, therefore, neither could any unborn child. If a mother was not a slave, then the Thirteenth Amendment was not necessary to end the enslavement of unborn children because there is no way an unborn child could become a slave. Although, in the context of manumission, the Tennessee court denied a man his freedom despite the fact that he was born to a soon-to-be-free woman.

The Supreme Court of the United States denied a grown slave, Sydney, his freedom despite his mother being promised her freedom 
before his actual birth. ${ }^{159}$ The Court recognized that Sydney was "freeborn" but still denied his freedom at the time of trial. Rather than denying his freedom because he was a slave before birth, Sydney lost the case in favor of a slaveholder who had purchased Sydney. The case may have turned out differently if Sydney had never been sold because the Court would not have had the competing interest of a third-party purchaser. A legal theory rendering void the purchase of a free man by a slaveholder who was unaware of the man's freedom would have placed a heavy burden on slave trade by requiring slaveholders to investigate each purchase, which the Court was unwilling to do. Instead of implying that unborn children were slaves, the Court's holding signifies a willingness to protect the fugitive slave laws and rights of a purchasing slaveholder at the expense of the rights of free blacks. Nonetheless, slavery's indirect effects upon unborn life and the lack of express inclusion of embryos suggest that the Thirteenth Amendment was not intended to apply to human embryos at the time of ratification.

\section{The Spirit of the Laws Encourage Human-Embryo Patents}

Current legal recognition of the human embryo suggests that humanembryo patents would be welcomed by the law rather than thwarted by the Thirteenth Amendment. Today, the prevailing understanding of the human embryo is that it represents potential for human development rather than "life in a special sense," and the law does not afford the embryo protection except in circumstances where the development potential of the embryo is implicated or threatened. As recognized by the scientific community, the human embryo cannot be equated with a fully functioning human being absent any indicia of a nervous system. The law has responded to scientific understanding by failing to classify the embryo as a constitutional "person" and instead recognizes and respects the embryo only for its potential.

The "pervading spirit" of the Thirteenth Amendment does not reflect the same concern for embryonic potential as do other laws that currently recognize the embryo. Legal recognition of the embryo in custody disputes, abortion law, criminal law, and common law arise out of circumstances straddling the life and death of the embryo and preservation of potential. Bear in mind, African slavery involved arbitrary subordination of individuals and communities, and the Thirteenth Amendment safeguards persons from the evils associated with

159. See supra Part II.C.2.a (discussing the laws of manumission as applied to unborn children). 
arbitrary domination. Essentially, the Thirteenth Amendment encompasses a much broader goal than current legal recognition of the embryo - that of preserving individual autonomy during life. The preservation of individual autonomy does not reflect the law's concern for preserving the potential of embryos because autonomy and physical development are not synonymous. Just because one lacks autonomous freedom does not mean that their potential for physical development is threatened, and just because one's physical development is threatened does not mean their autonomy goes unpreserved. For instance, civil and criminal laws, such as torts and murder, preserve the physical potential, or realization of potential, for human life, but these laws are not sufficient to guarantee autonomous freedom-hence the need for the Thirteenth Amendment. Yet the Thirteenth Amendment is not sufficient for protecting physical potential, or realization of potential-hence the need for the criminal laws and torts. Although the government has a substantial interest in preserving potential for human development, as of now the embryo does not have protection from the law beyond direct preservation of life and potential because the embryo is not a constitutional "person" with full legal rights. Therefore, the Thirteenth Amendment's guarantee of autonomy during life does not match the type of protection currently afforded in other areas of law and should not apply to human embryos.

In fact, human-embryo patents would help guard and promote embryonic potential. Notably, the existence of a patent does nothing to diminish the embryo's potential - the act of obtaining and actually owning a patent does not physically affect embryos. Instead, humanembryo patents would help guard and promote embryonic potential rather than threaten embryonic potential, as contemplated in other areas of the law. Because the spirit of patent law is to promote commercialization and innovation, a patent would promote embryonic potential by encouraging inventors to invest in embryonic technologies. With a patent, the patent holder would exploit their limited monopoly by investing in new techniques that are safer and more efficient than existing technologies. In addition to encouraging technological advances, a human-embryo patent would create a form of private regulation regarding patented embryonic technology. Because only the patent holder would be able to license and practice the invention in the absence of governmental prohibition, anyone else practicing the invention would have to seek approval from the patent holder. ${ }^{160}$ 
Although the subject matter of the patent, such as a process for embryo manipulation, may have consequences that affect the embryo's potential, these consequences exist whether or not the inventor obtains a patent, because in the absence of a patent, people will still practice the technology. When compared to the spirit of legal recognition of the human embryo in general, human-embryo patents should be encouraged as a means for promoting technological advancement and private regulation.

\section{B. Interpretation of "Involuntary Servitude" Does Not Account for Embryos}

Essentially, the Supreme Court interprets "involuntary servitude" as a prohibition against infringement of an individual's autonomy resulting in compulsory labor through means of physical or legal coercion. As previously discussed, ${ }^{161}$ the potential psychological effects on children born as a result of reproductive embryonic technologies do not violate the Thirteenth Amendment because they are not a means for compelling labor. And even if they were, psychological coercion is excluded from the definition of "involuntary servitude." Additionally, there are concerns regarding the physical abnormalities of children born as a result of embryonic technologies. ${ }^{162}$ However, similar to psychological concerns, the physical harms are not caused for the purpose of compelling labor, and they may be avoidable with the advancement of technology. The analysis of the Court's interpretation, however, is not complete without discussing whether it applies to life at the embryonic stage. Application of the Thirteenth Amendment has never involved unborn life, and therefore interpretation of the Amendment has resulted in the use of language, such as "coercion" and "labor," that is difficult to apply to the human embryo.

\section{Physical and Legal Coercion of Embryonic Life}

Legal and physical coercion of life at the embryonic stage differs drastically from any possible coercion of "life in a special sense" simply because of their different stages in the timeline of human development. Broadly defined, coercion means the use of "force or intimidation to

should not be prohibited)

161. See supra Part II.C.2.b (discussing the Court's interpretation of "involuntary servitude")

162. AM. MED. Ass'N, supra note 150, at 3; Andrews, supra note 148, at 652. 
obtain compliance."163 First, a postnatal human being has some sort of capacity for understanding legal threats and sanctions, whereas an embryo has no means for detecting such actions. Issuance of a patent could constitute legal coercion of the embryo, but there is no rational way of concluding whether the legal imposition of a patent is "involuntary" given the absence of cognitive ability in the embryo for recognizing such legal action. One could argue that some postnatal human beings, such as incompetent or less competent persons, cannot understand a legal threat. Therefore, the ability to understand a legal threat cannot provide the basis for distinguishing between the human embryo and "life in a special sense," because surely incompetent or less competent postnatal humans can be considered enslaved. However, this argument fails to account for the varying degrees of understanding of "life in a special sense" and the complete inability of an embryo to understand because it lacks nerve cells and a nervous system. In contrast, human life beyond the embryonic stage has a nervous system and therefore, has at least some capacity for understanding. Even still, it seems difficult to conceptualize the legal coercion of a fetus, or even a newborn, as being similar to the coercion used by slaveholders given the relatively low level of rational thought at these early developmental stages.

Second, physical coercion of an adult human being involves pain and suffering, whereas any possible physical coercion of an embryo could not possibly involve pain and suffering absent a nervous system. In fact, it is quite difficult to equate the physical coercion associated with slavery, such as physical abuse, with any physical actions associated with an embryo, such as in vitro fertilization, embryo screening, cloning, and genetic manipulation. Physical coercion of postnatal human beings denotes unwanted physical contact; however, physical coercion of an embryo may not always be undesirable. For instance, in vitro fertilization allows for embryos to develop into postnatal human beings that otherwise would not exist due to infertility problems; embryo screening allows parents to choose which embryo has the best chance for survival and development; and genetic manipulation could possibly prevent diseases and illnesses that are otherwise untreatable. None of these technologies inherently involves the type of physical coercion imposed upon slaves and addressed by the Thirteenth Amendment. Therefore, it is a big leap to assume that "coercion," as used in the

63. Dictionary.com, http://dictionary.reference.com/browse/coercion (last visited Mar. 29, 
Court's interpretation of the Thirteenth Amendment to postnatal human beings, is inclusive of any possible coercion of a human embryo.

\section{Embryonic Labor and Autonomy}

The type of labor associated with slavery and contemplated by the Court differs from the type of labor an embryo performs. Sure, an embryo does labor in the form of physical "work" as understood for physical processes, ${ }^{164}$ and a patent holder stands to gain financially from the result of this work just as a slaveholder gained from slave labor. But the type of physical movement associated with an embryo is different from the manual labor performed by a slave. Slave labor was an active endeavor where a slave made the conscious decision, although compelled and against his will, to perform the labor. Compelling slave labor was a two-step process involving the actions of the slaveholder coercing the slave to work followed by the slave's conscious submission to the coercion. On the contrary, labor performed by an embryo is passive, meaning that the embryo does not make a conscious decision to perform work, but instead reacts to its environment. A patent holder can compel the embryo to react in certain ways by altering the chemical environment, but even absent compulsion, an embryo will perform its work nonetheless. Therefore, the work of the embryo cannot be compelled despite the fact that an inventor can dictate the results of the work. The Court's use of the word labor implies the strong presumption that the type of compulsory labor the Thirteenth Amendment ended is of a kind inapplicable to the human embryo.

The Court's interpretation of "involuntary servitude" implicates the autonomy of the slave, which is different from that of a human embryo. Autonomy generally means independence, self-governance, and freedom from arbitrary exercise of authority over one's will, which is implicated by the Court's acknowledgement that any labor prohibited by the Thirteenth Amendment must be compelled. ${ }^{165}$ Philosophers have grappled with the definition of autonomy and free will as applied to the cognitive abilities of the human species, yet the human embryo lacks any cognitive capacity. This begs the question: What is the autonomy of the embryo? Any autonomy ascribed to the embryo would exist by virtue of its ability to react naturally to its environment without unnatural

164. See David Halliday et Al., Fundamentals of Physics 118 (6th ed. 2001) (defining work as "energy transferred to or from an object by means of a force acting on the object").

165. Dictionary.com, http://dictionary.reference.com/browse/autonomy (last visited Mar. 29, 2007) 
interference. One could argue that any direct infringement on the embryo's natural development infringes upon its autonomy. ${ }^{166}$ This interpretation, however, differs significantly from the autonomy of human "life in a special sense," which is presented with choices and makes rational decisions based upon past experiences and future consequences. An embryo does not "make decisions" or "have experiences" in the same way as a postnatal human being, and so reference to the embryo as having autonomy does not account for the embryo's lack of rational thought. Any autonomy of an embryo is distinguishable from that of human "life in a special sense" because the embryo is not capable of rational thought. Words such as autonomy, coercion, and labor, as used in the context of slavery, are inapplicable to human life at the embryonic stage, and therefore the Supreme Court's definition of the range of circumstances triggering the Thirteenth Amendment's prohibition against "involuntary servitude" is inapplicable to the human embryo.

\section{A Comparative Analysis of the Property Rights Associated with Slavery and Patents}

Regardless of whether or not the Thirteenth Amendment applies to human embryos, the Amendment does not preclude human-embryo patents because the Amendment ended the unique relationship between slaveholder and slave rather than mere property ownership of man. McDonald's argument claims that the Thirteenth Amendment ended all property ownership in human beings by reducing the slaveholder-slave relationship to mere property ownership, and thus equating the complex relationship between slaveholder and slave to the property interest of a patent. However, the Supreme Court has held that the Thirteenth Amendment prohibits situations "akin to African slavery," and there are two sharp distinctions between the slaveholder-slave relationship and human-embryo patents that put the two on unequal footing: (1) the slaveholder-slave relationship was a hybrid of property and agency, whereas a patent involves pure property; and (2) the right of a slaveholder was an affirmative right, whereas a patent bestows upon its holder a negative right. Although McDonald argues that the Thirteenth Amendment ended all property ownership of human beings,

166. See SILVER, supra note 36, at 50 ("If the word natural is used to mean the most likely outcome nature will take in the absence of any external interference . . ., then the natural destiny for the human embryo is death" because seventy-five percent of all naturally fertilized eggs die before birth.). 
acknowledging the fundamental differences between slavery and patents makes it a challenging comparison.

\section{Property-Agency Hybrid vs. Pure Property}

Despite common references to slavery as man owning man as property, at least one slave state's highest court, the Supreme Court of Tennessee, explicitly relied upon agency law for determining outcomes of disputes between slaveholders. Furthermore, the Supreme Court of the United States implicated the agency aspect of slavery through its interpretation of the phrase "involuntary servitude." In contrast, a patent involves pure property law and does not necessitate nor invoke agencylaw analogies. A patent holder merely has the right to exclude others and has no right to interact with the subject matter of the patent, especially in any way reminiscent of agency. This drastically differs from the property-agency hybrid of slavery suggested by state and federal courts.

The Supreme Court of Tennessee's struggle in classifying slaves purely as property and the need for agency analogies for resolving disputes between slaveholders suggest that the Thirteenth Amendment ended something other than man owning man as property. Although scholars and historians have classified slaves as property, this classification seems to be more out of convenience than accuracy because it ignores the inescapability of agency analogies arising from the unusual value of slaves as "thinking property." Bolstering the analogy between slavery and agency is the Supreme Court's interpretation of "involuntary servitude," which prohibits the legal and physical coercion of compulsory labor. This interpretation essentially ended working relationships based upon force and duress where the employee has no choice but to work, which bears little relation to property law. Although the Supreme Court of Tennessee never fully adopted agency law as the governing law for slavery and the Supreme Court of the United States has never explicitly addressed the agency-aspect of slavery, the slaveholder-slave relationship could never be reduced to mere property ownership given the unique value of the slave as "thinking property."

Subordination of "thinking property" in the context of African slavery in the United States was arbitrary and inhumane; but humanembryo patents are neither. African enslavement was arbitrary because it was based upon subjective notions of racial superiority between members of the same species. Slavery was inhumane because it involved merciless treatment of members of the human species for the purpose of imposing upon their will. Patented technologies involving human embryos, however, do not involve subordination, arbitrariness, or 
inhumanities similar to those involving slavery. First of all, subordination implies something of a lesser or inferior value, and patenting a human embryo is not a result of it being lesser or inferior. Rather, it revolves around commercialization and innovation, of which the embryo just so happens to be a part. Remember, a slave was "thinking property," but the human embryo cannot be so characterized because it lacks a nervous system, preventing any possible brain function. Accordingly, the means for subordinating "thinking property" is different in nature than subordination of an embryo. Moreover, the use of human embryos is not arbitrary - the use derives from the unique position of the embryo in the timeline of human development. The embryo has the requisite genetic properties for human development, yet the early stage of development at which the embryo exists allows for unique opportunities for scientific technology. Although some disagree over whether human-embryo technologies are humane, it is not universally agreed that the burdens of human-embryo technologies outweigh the benefits. But today it is generally agreed that any benefit of slavery is outweighed by its inhumanities. The complexity of the property-agency relationship between slaveholder and slave derives from the slave being "thinking property" and distinguishes the slaveholderslave relationship from human-embryo patents. Absent agency-type analogies for nonthinking property, human-embryo patents cannot create a relationship "akin to African slavery." 


\section{Affirmative Right vs. Negative Right ${ }^{167}$}

The differences arising from the affirmative-negative distinction between slavery and patents exhibit why the Thirteenth Amendment should not be assumed to prohibit all property ownership of man, but rather should only outlaw relationships that are comparable to that of slaveholder and slave. The affirmative nature of the slaveholder-slave relationship drastically differs from the negative property rights associated with a patent in terms of the rights conferred, duration of the relationship, physical control over the subject matter, and assertion of right upon infringement. The Thirteenth Amendment specifically ended the affirmative right of a slaveholder to control his slaves and has never been held to end any negative property right, such as the rights associated with a patent. The affirmative right of a slaveholder is apparent from the property-agency nature of the slaveholder-slave relationship where the slaveholder had the right to direct the slave for his own benefit. However, a patent holder's negative property right only allows her to exclude others from making, using, or selling the patented invention and does not give any affirmative right to practice the

167. Property interests can be affirmative or negative but not both. See Tibor R. Machan, The Perils of Positive Rights, THE FREEMAN: IDEAS On LiBerTy, Apr. 2001, at 49, 49, available at $\mathrm{http} / /$ www.fee.org/publications/the-freeman/article.asp?aid=2993 (discussing the inherent conflict between "positive" and "negative" rights). An affirmative property interest entitles the property holder to "goods or services at the expense of other persons" whereas a negative property interest prevents "uninvited interventions of others." $I d$. The property interest associated with a patent is negative because it allows the patent holder to exclude others from making, using, or selling their invention. See MERGES ET AL., supra note 3, at 126 (describing why a patent property interest is a negative interest). Alternatively, the property interest associated with slavery was affirmative because it allowed the slaveholder to reap the benefits of the slaves' services to the detriment of the slaves. See Andrew Fede, Legitimized Violent Slave Abuse in the American South, 1619-1865: A Case Study of Law and Social Change in Six Southern States, 29 AM. J. Legal Hist. 93, 94 (1985), reprinted in ARTICLES ON AMERICAN SLAVERY: LAW, THE CONSTITUTION, AND SLAVERY 31, 32 (Paul Finkelman ed., 1989) (noting that "Africans who had been enslaved and who survived the tragic transatlantic slave passage were sold to buyers who bargained for the exclusive right to reap the fruits' of the slaves' labor, which the owners enforced by exercising their right to 'uncontrolled authority' over the slave" (emphasis added)).

The affirmative interest of a slaveholder, however, cannot be reduced to mere property ownership because the Supreme Court of Tennessee made analogies between slavery and the laws of agency. See Corré, supra note 109, at 439-47 (confirming the court's rejection of pure property law analysis for cases involving the vicarious liability of a slaveholder for his slave's actions and the conversion of a slave's services). The Supreme Court of the United States never considered a pure property approach for interpreting the Thirteenth Amendment and instead holds that the amendment prohibits situations "akin to African slavery," ultimately implying an agency relationship by interpreting the Thirteenth Amendment to prohibit compulsory labor. See United States v. Kozminski, 487 U.S. 931, 942 (1988) (recognizing that the Thirteenth Amendment ended African slavery and circumstances reminiscent of African slavery); Butler v. Perry, 240 U.S. 328, 332 (1916) (stating that the Thirteenth Amendment was intended "to cover those forms of compulsory labor akin to African slavery which in practical operation would tend to produce like undesirable results"). 
invention or interact with the patented subject matter. Any right to practice the invention is by virtue of governmental acquiescence, or lack of governmental prohibition, and the absence of other patents on the same subject matter. For instance, a world without patents would allow anyone and everyone to practice invention $X$. Now, in a world with patents, only the patent holder can practice patented invention $\mathrm{X}$ because only she has the right to exclude the rest of the world from making, using, or selling the invention. However, if the government prohibits the practice of invention $\mathrm{X}$, the patent holder still has the negative property right of exclusion but cannot take any affirmative action to practice the invention. Although the Thirteenth Amendment is commonly referred to as ending property ownership of man, it has only been applied to preclude the affirmative right to control others and not the negative right to exclude.

McDonald's argument incorrectly states that:

The right to manufacture would give the patent holder the right to reproduce, or clone, the human being and to exclude others from cloning that human being. . . .

The right to use would give the patent holder the right to control the human being's activities and to prevent others from interacting with the human being. ...

The right to sell would give the patent holder the right to contract out, or sell, the human being and his services. ${ }^{168}$

Although her argument initially acknowledges that a patent right is a negative interest, the example is misleading because it incorrectly implies that the patent holder has an affirmative right to manufacture, use, and sell the invention. Despite this misapplication, McDonald's argument raises the point that the patent holder might assert even a negative property right in an adverse way. For example, it could be used to prevent others from making, using, or selling the patented invention in situations where the patented technology is essential for preserving an embryo's potential. In such situations, the law would have to allow for an exception, similar to the medical-use exception, which excuses liability for certain patent-infringing actions. ${ }^{169}$ Otherwise, an embryo's developmental potential could be threatened, which would be contrary to the spirit of the laws recognizing the importance of embryonic life. Still,

168. McDonald, supra note 17, at 1385.

169. See 35 U.S.C. $\S 287$ (2000) (allowing medical practitioners to infringe certain types of patents without affording the patent holder any legal remedy against the medical practitioner). 
based upon the context in which the Thirteenth Amendment was ratified, the distinction between affirmative and negative rights is important for determining what the Amendment ended.

The distinction between affirmative and negative rights is also important for determining against whom the patent holder is able to assert his or her right upon a finding of infringement. In the context of slavery, a slaveholder's right could be infringed either when the slave disobeyed authority, such as by running away or refusing to work, or by third parties, such as conversion of services. In situations of third party infringement, either the laws of property or agency would determine the outcome of a dispute. But in situations of disobedience of the slave, a slaveholder would assert his right directly by punishing, selling, or finding ways to make the slave work. On the other hand, a humanembryo patent holder would never assert her negative property right against the embryo because the embryo is the subject matter from which others are being excluded and there is no affirmative right to the embryo itself, thus making it impossible for any action of the embryo to infringe a right of the patent holder. Essentially, the vulnerable party in the slaveholder-slave relationship is shielded from actions of infringement by the Thirteenth Amendment because the Amendment took away the slaveholder's legal right over the slave. Yet the vulnerable party in the human-embryo patent relationship - the human embryo-needs no shielding from actions of infringement because the subject matter of a patent cannot infringe its own patent. Therefore, one of the Thirteenth Amendment's benefits in the context of slavery, shielding vulnerable victims from infringement actions, does not exist in the context of human-embryo patents.

Finally, the negative property right associated with a patent avoids two harms associated with slavery-seemingly unlimited duration of control and direct physical control. The negative property right of a patent gives the patent holder a monopoly for practicing the invention by virtue of the patent holder's right to exclude others. But the patent system attempts to maximize the fairness of the monopoly by limiting the effectiveness of the patent to a term of twenty years. ${ }^{170}$ The implication of patent expiration is that the patent holder's right to exclude disappears and the patented subject matter enters the public domain for everyone to make, use, or sell. Alternatively, the relationship between slaveholder and slave did not have a readily identifiable ending

170. See Merges ET AL., supra note 3, at 126 (noting that the patent term for utility patents is twenty years from the filing date). 
date, meaning that the slave was under the direct physical control of the slaveholder indefinitely. Direct physical control may have existed in the slaveholder-slave relationship, but with the commercialization of a patented invention comes the transfer of physical control of the commercialized item. In the context of a human-embryo invention, the patent holder would most likely license a process incorporating the human embryo or sell actual embryos to third parties. Although the patent holder has physical control over the subject matter for a period of time, the inevitable commercialization of the patented subject matter involves third parties who also have physical control over the invention. Despite the lack of physical control, the patent holder still maintains its right to exclude others. The ability of a patent holder to maintain its negative property interest in the patented invention without having direct physical control over the subject matter differs from a slaveholder's direct control over his slaves. The affirmative-negative distinction between the slaveholder-slave relationship and human-embryo patents demonstrates that the two are distinct from one another and present separate issues. Given that the Thirteenth Amendment is limited to prohibiting conditions "akin to African slavery," human-embryo patents should not be prohibited by the Amendment because they are not comparable to the slaveholder-slave relationship.

\section{Other Considerations for Concluding that the Thirteenth Amendment Should Not Prohibit Human-Embryo Patents}

The Thirteenth Amendment is not the proper tool for policing the use of human-embryo technologies because it ignores the constitutional origins of the patent system, prohibits all patenting of human-embryo technologies rather than determining the good from the bad, and excludes the use of patents as a form of private regulation. Comments by the USPTO and McDonald are minimally persuasive legal authority for determining whether the Thirteenth Amendment precludes humanembryo patents because these comments are not valid law, and in fact, valid law allows for the patenting of human-embryo inventions based on the Court's declaration that patentable subject matter includes anything man-made. Nonetheless, the USPTO denies that patentable subject matter includes human life altered by man.

The patent system and the Thirteenth Amendment originate in the Constitution and, despite their apparent conflict, they can be reconciled with one another. Notably, the constitutional grant creating a patent system carries greater weight than the Thirteenth Amendment because it appears in the original Constitution rather than as an Amendment. 
However, at the time of ratification of either the Constitution or Thirteenth Amendment, human-embryo patents could hardly have been anticipated. Human-embryo patents, therefore, present unanticipated issues resulting in an unforeseen potential conflict between constitutional laws. Constitutional conflict is not unique to human-embryo patents and the Thirteenth Amendment as displayed by the conflict between copyright laws and the First Amendment. Copyright law allows the holder of a copyright the exclusive rights, among several others, of copying and distributing the copyrighted material. ${ }^{171}$ This implicates the guarantee of free speech attributed to the First Amendment because those other than the copyright holder infringe the copyright holder's rights when expressing the copyrighted material without permission. ${ }^{172}$ Despite the tension between copyright law and freedom of speech, the two have compromised and found ways to coexist without one completely trumping the other. The tension and compromise affecting copyright law and freedom of speech serve as a good analogy for human-embryo patents and the Thirteenth Amendment. The legal system should not feel pressure to choose a "winner" between the patent system and Thirteenth Amendment because it would be a shame for one to usurp the importance of the other.

The patent system and the Thirteenth Amendment serve distinct but important functions in the legal system and United States culture. The Thirteenth Amendment ended the institution of slavery in the United States and is a reminder of the evils associated with slavery that we seek to avoid. Alternatively, the patent system serves as a reward for innovation and an inducement for commercialization of new technologies. Essentially, one is a correction of past mistakes and the other is encouragement for a better future. The apparent conflict between the two encourages consideration of the consequences concerning preemption of one by the other. Failure to consider the Thirteenth Amendment in the context of human-embryo patents would result in overlooking the uniqueness we attribute to the entire human species, as supported by the promotion of equality of all shapes, sizes, colors, and phases of human life. This is not to say that the remedy of the Thirteenth Amendment, for the purpose of ending arbitrary enslavement, is the same remedy necessary for preserving the respect of the human embryo. Preemption of human-embryo patents by the Thirteenth Amendment would preempt all human-embryo patents, thus

171. 17 U.S.C. $\S 106(2000)$.

172. MERGES ET AL., supra note 3, at 506-07, 552-53. 
discouraging innovation in an area where there are positive and negative implications unique to the field of embryonic technology. Instead of a complete prohibition of human-embryo patents, the law should seek to regulate the use of human-embryo technologies and separate the good from the bad. In fact, patents actually serve as a form of private regulation that could help preserve respect for the human embryo and associated technologies.

The patent holder's right to exclude others from making, using, or selling a patented technology is exclusive and serves the function of private regulation. Private regulation is achieved through the patent holder's policing the patented technology to prevent unauthorized practice of the patented invention. Absent a patent and subsequent policing of the patent, nothing other than the possibility of governmental prohibition stands in the way of others wishing to practice the invention. Patents serve to limit who practices the invention by granting the patent holder the legal authority to exclude others. This means that a patent holder can decide who can and cannot practice the invention, which could possibly prevent the irresponsible practice of a technology by those unqualified to do so. Because patents serve as a form of private regulation, those who dislike human-embryo technologies should actually celebrate the patenting of human-embryo technologies to prevent irresponsible practices in the absence of government regulation or prohibition. In fact, private regulation may actually serve as a stronger form of regulation than governmental regulation because typically those practicing in a specific field know the activities of their peers and may be more aware of irresponsible practices than the government. Opponents to human-embryo patents may be confusing promotion of innovation and commercialization with the amount of actual practice of an invention. If patents are not allowed for humanembryo technologies, inventors are still going to practice these technologies. However, absent a patent, the inducement to commercialize is severely lessened because there is no limited monopoly for recovering the cost of investing in the technology. Therefore, patents do not necessarily promote the actual practice of an invention, but instead, promote commercialization and private regulation. Such considerations should not be ignored when determining the legality of human-embryo inventions.

\section{CONCLUSION}

The Thirteenth Amendment is not the correct means for prohibiting the patenting of human-embryo inventions and the legal system should 
look elsewhere for regulation of such technologies. The Amendment does not apply to unborn life because it was not intended to apply at the time of ratification and a modern court would not interpret the Amendment to apply to human embryos today. However, even if the human embryo was within its scope, human-embryo patents do not violate the Thirteenth Amendment because they do not create a relationship sufficiently similar to that of slaveholder and slave. At the time of ratification of the Thirteenth Amendment, human-embryo patents were unimaginable, and therefore lawmakers did not consider the effect of laws upon patenting human life. Now that technologies exist that incorporate the human embryo, the law should take a fresh look at the issues presented by such technologies rather than rely on precedent that fails to even consider their possibility. Rather than prevent all embryonic technologies with the broad swipe of the Thirteenth Amendment, the scientific and legal communities should consider the actual issues posed by human-embryo patents and seek instead to regulate their use. 